\title{
Way of life and survival strategies in earthquake adapted settlements in Turkey
}

\section{Introduction}

Cities are diversified allocation units which keep various lifestyles together. During the process of urbanisation, immigrants who have just migrated to cities mostly settle in residential areas in line with their socio-economic status. Thus different 'housing classes' (Saunders, 1984) which come together based on similar features are diverged from each other by different 'ways of life'. Diversification of 'ways of life' in urban areas is a long-discussed issue in the urbanology literature.

Louis Wirth, in his article Urbanism as a Way of Life (1938), states that the achievement of an adaptable approach for analysing basic structures that societies have formed within the modern process of urbanity may be possible by treating urban-industrial and rural-public communities as ideal community structures. According to him, urbanisation not only denotes a process of attracting people to residences defined as cities but also implies the adoption of an urban way of life. Within this framework, ties between relatives, neighbourhood and traditional communal emotions disappear or stand an optimum chance of being weakened. Personal, artificial, temporary and partial 'secondary relations' take the place of 'primary relations'.

On the other hand, Herbert J. Gans (1962) argues that Wirth's approach has lost its appropriateness in present-day cities. In his view, Wirth's suggestions are more applicable to the residents of central urban areas and urban industrial societies than cities. However, it is not proper to identify urbanisation and the types of urban relations that Wirth has defined with all urban areas, due to the extension of modern cities into large areas and the rise of suburban areas. This is so as a result of the settlement of new immigrants in inner cities bringing new ways of life to the city. Gans points out that such immigrant groups, which he calls 'ethnic villagers', pursue traditional/rural ways of life isolated from the other parts of city as a result of which a 'suburban way of life" has arisen. Nevertheless, at this point, transformations in suburban areas have brought diversifications within such areas themselves. Therefore, more than one way of urbanism may be found instead of a single pattern of urbanism.

Oscar Lewis (1959) directly relates the way of life to poverty and explains the way of life of the poorest villagers and workers in urban centres with a concept which he calls the 'culture of poverty'. Immigrants from rural areas, the mass of unemployed people and low income groups in urban centres settle in similar communal residences and form a new cultural area (Türkdoan, 1974: 4-5). Lewis, in his Five Families: Mexican Case Studies in the Culture of Poverty, lists the main conditions for the rise of such cultural areas - that is, the 'culture of poverty' - as follows:

1. a cash economy, wage labour and production for profit

2. a persistently high rate of unemployment and the under-employment of unskilled labour

3. low wages

4. the failure to provide social, political and economic organisation, either on a voluntary basis or by government imposition, for the low-income population 
5. the existence of a bilateral kinship system rather than a unilateral one

6. the existence in the dominant class of a set of values that stresses the accumulation of wealth and property, the possibility of upward mobility and thrift and which explains low economic status as the result of personal inadequacy or inferiority (Lewis, 2000: 111).

The appropriateness of Lewis's 'culture of poverty' concept has also been questioned in relation to squatters in Türkiye. It has been revealed by Türkdoan's (1974) research that squatters in Türkiye are diversified in some respects from their peers in middle and south America, but it has been concluded that the community of people immigrating from rural to urban areas continuously form a new culture amongst squatters, as Lewis has argued.

Many other research studies have been carried out in Türkiye in the arena of squatters (for instance: Hart, 1969; Karpat, 1976; enyapl, 1983). Yet, there exists no study which has dealt with earthquake adapted settlements, which have similar features in terms of poverty and way of life, within the above-mentioned framework. Within this framework, this article therefore discusses the way of life (culture) in poor quarters of Türkiye and the impact of such a culture on inclusion in the city via the presentation of such a culture particularly in earthquake adapted settlements. To this end, this study focuses on the relationship between way of life and urban living strategies, including survival in the city.

\section{Methodology}

The research area covers squatter settlements and the temporary prefabricated housing (prefabricated housing) and permanent earthquake adapted housing (earthquake adapted settlements) which were constructed in Bolu, Türkiye after the 1999 earthquake and which are regarded as having similar features in terms of poverty and way of life (Ulusoy and Kayıkçı, 2006). The sampling scheme was of a multi-phase type. In the primary phase, information was gathered about the household and, in the second phase, similar surveys were conducted with the head of the family and the spouse as a sub-set of the household. Bolu was taken as the central research sphere and was divided into two sub-spheres. Each sub-sphere is a layer, constituted by prefabricated housing districts and permanent housing.

The prefabricated housing layer covers the four districts of Karaçayır, Çankırı, Ankara and Seda, while the earthquake adapted settlements layer covers the two districts of Umutkent and Yașamkent. In both layers, households were selected from lists received from the administrations of prefabricated housing districts and earthquake adapted settlements. A systematic random selection method was used in this selection. The study schedule and the sampling scheme in these areas were carried out considering the order that prefabricated housing districts should be abolished. For instance, a random point was selected and all the neighbouring households were questioned. Concerning earthquake adapted settlements, a systematic random selection method was applied where the neighbourhood requirement for the households was not deemed necessary.

\section{Demographic characteristics}

The demographic characteristics of the residents of earthquake adapted settlements include age, marital status, education, social security and working life. 
The distribution of the residents in terms of sex and age groups is given in the following Table 1. Accordingly, young people (younger than 34) constitute the majority of residents $(61.3 \%)$. In terms of sex, the number of females is almost equal to the number of males.

Table 1 - Distribution of residents by age groups and sex

\begin{tabular}{|l|c|c|c|}
\hline Age group & Male & Female & Total \\
\hline $0-4$ & 30 & 38 & 68 \\
\hline $5-9$ & 55 & 46 & 101 \\
\hline $10-14$ & 56 & 41 & 97 \\
\hline $15-19$ & 51 & 39 & 90 \\
\hline $20-24$ & 45 & 64 & 109 \\
\hline $25-29$ & 51 & 59 & 110 \\
\hline $30-34$ & 56 & 55 & 111 \\
\hline $35-39$ & 36 & 43 & 79 \\
\hline $40-44$ & 42 & 36 & 78 \\
\hline $45-49$ & 41 & 39 & 80 \\
\hline $50-54$ & 26 & 29 & 55 \\
\hline $55-59$ & 23 & 23 & 46 \\
\hline $60-64$ & 11 & 13 & 24 \\
\hline $65-69$ & 6 & 15 & 21 \\
\hline $70+$ & 20 & 29 & 49 \\
\hline Total & 549 & 569 & 118 \\
\hline
\end{tabular}

Table 2 indicates that two-thirds of the total population of earthquake adapted settlement residents who are of marriageable age are already married, which shows a positive approach towards the concept of marriage. In addition, there is no distinct separation regarding marital status on the basis of sex as there was in the distribution regarding age groups.

Table 2 - Marital status by sex

\begin{tabular}{|l|c|c|c|}
\hline Marital status & Male & Female & Total \\
\hline Married & 263 & 266 & 529 \\
\hline Single & 161 & 120 & 281 \\
\hline Widow & 9 & 55 & 64 \\
\hline
\end{tabular}




\begin{tabular}{|l|c|c|c|}
\hline Marital status & Male & Female & Total \\
\hline Divorced & 5 & 16 & 21 \\
\hline Other & 6 & 6 & 12 \\
\hline Total & 444 & 463 & 907 \\
\hline
\end{tabular}

Where educational background is concerned, the ratio of males in education as a percentage of the total population of school age is as high as $95 \%$ while this figure decreases to $85 \%$ for the female population. Such a situation mostly occurs in low socioeconomic strata of society and is an indicator of the socio-economic situation of residents in earthquake adapted settlements (Table 3).

Table 3 - Whether in education or not, by sex

\begin{tabular}{|l|c|c|c|}
\hline & Male & Female & Total \\
\hline In education & 482 & 444 & 926 \\
\hline Not in education & 23 & 75 & 98 \\
\hline Total & 505 & 519 & 1024 \\
\hline
\end{tabular}

The percentage of females with only primary or secondary education is rather high (62.9\%). As for higher educational levels, the percentage of people with a high school education and who are females is as low as $10.4 \%$ while the percentage of people who are faculty graduates and who are also women is $7.9 \%$ (Table 4).

A similar distribution can be seen among males; however, the number of male high school and faculty graduates is a little higher than the number of females. Accordingly, the percentage of males who attended only primary and secondary school ${ }^{1}$ is $56.4 \%$, while the percentage of high school graduates is $24.1 \%$ and, lastly, the percentage of faculty graduates is $19.7 \%$. The presence of a minority of higher education graduates both among males and females gives rise to the thought that people other than earthquake victims also reside in earthquake adapted settlements and such people tend to benefit from the economic privileges offered mostly in prefabricated housing areas.

Table 4 - Educational background, by sex

\begin{tabular}{|l|c|c|c|}
\hline & Male & Female & Total \\
\hline Primary school & 190 & 237 & 427 \\
\hline Secondary school & 82 & 42 & 124 \\
\hline High school & 116 & 93 & 209 \\
\hline Faculty & 95 & 73 & 168 \\
\hline
\end{tabular}

1 According to Law No. 4306 adopted in 1997, the mandatory primary education period was increased from five years to eight. 


\begin{tabular}{|l|c|c|c|}
\hline & Male & Female & Total \\
\hline Other & 1 & 2 & 3 \\
\hline Total & 482 & 444 & 926 \\
\hline
\end{tabular}

The social security situation of residents of earthquake adapted settlements is as follows: the percentage of those who have insurance in any way is $73.4 \%$. These figures represent $71.9 \%$ for males and $74.8 \%$ for females, i.e. there is not a significant difference. The people insured by SSK (the Social Security Institution) and the Pension Fund constitute $70 \%$ of the total number of people who have insurance in earthquake adapted settlements (Table 5).

Table 5 - Social security institution, by sex

\begin{tabular}{|l|c|c|c|}
\hline Social Security Institution & Male & Female & Total \\
\hline SSK $*$ & 182 & 200 & 382 \\
\hline Pension Fund & 89 & 110 & 199 \\
\hline Bakur** & 32 & 39 & 71 \\
\hline Green Card & 89 & 75 & 164 \\
\hline Private insurance & 1 & - & 1 \\
\hline Other & 2 & 2 & 4 \\
\hline Total & 395 & 426 & 821 \\
\hline
\end{tabular}

* Social Security Institution

** Social Security Organisation for Artisans and the Self-Employed

Some $44 \%$ of the total male population over the age of 12 (which is regarded as the age of starting work) are in work. The percentage of working females is low $(15 \%)$. That means that less than one-third of the total female population over the age of 12 are in work while the rest are not. That participation in working life is so low is particularly thought-provoking (Table 6).

Table 6 - Whether employed or unemployed, by sex

\begin{tabular}{|l|c|c|c|}
\hline & Male & Female & Total \\
\hline Employed & 224 & 77 & 301 \\
\hline Unemployed & 281 & 441 & 722 \\
\hline Total & 505 & 518 & 1023 \\
\hline
\end{tabular}

Students and housewives constitute nearly $70 \%$ of total population who are unemployed. Among males, the percentage of pensioners is fairly high. Again among males, the majority of those who identify themselves as 'unemployed' attracts attention (Table 7). 
Table 7 - What the unemployed are doing, by sex

\begin{tabular}{|l|c|c|c|}
\hline & Male & Female & Total \\
\hline Student & 145 & 122 & 267 \\
\hline Housewife & - & 260 & 264 \\
\hline Pensioner & 49 & 18 & 67 \\
\hline Elderly and unable to work & 10 & 20 & 30 \\
\hline Disabled & 5 & 7 & 12 \\
\hline Unemployed & 56 & 15 & 67 \\
\hline Soldier & 12 & - & 12 \\
\hline In prison & 4 & - & 4 \\
\hline Total & 281 & 442 & 723 \\
\hline
\end{tabular}

\section{Poverty}

Urban poverty, which displays itself in slum and squatter communities, is a structurally-created concept. Its roots extend to forces both inside and outside of society. At the abstract level, urban poverty indicates a dependence relationship. Slum/squatter life, insufficient nutrition, disease, guilt, immorality and prostitution could be recognised among the products of such a relationship.

Besides, urban poverty and social structures such as slum/squatter communities may be regarded as functional since they make the system tolerable. These are the adaptations of a special socio-economic system which struggles to tackle the contradictions arising in such a system without radically changing the existing socio-economic structure (Randolf, 1977: 83).

In this context, even the necessity of handling the concept of 'poverty' is sometimes stressed. For instance, according to a study carried out by Asiama regarding the poor regions of Ghanaian cities, the poverty of the residents of 'squatter' communities does not result from the insufficient income they earn; in contrast, a proportion of these may have higher incomes than civil servants or those with regular salaries who live in the city. Asiama suggests that the condition which makes these groups poor is their inability to reach some services from which other groups already benefit. Therefore, he emphasises the importance of re-defining the concept of 'poverty' by associating it with variables other than income, in particular with the quality of living accommodation (Erder, 1997: 37).

In general, cities have been being perceived as embodying the richness of civilisation, welfare and opportunities. Views and expectations regarding cultural and social aspects increase as the socio-economic level rises. However, when stepped downwards, physical structure and job opportunities stand at the forefront of urban image and connotations (Ayata and Ayata, 2000: 167). In this direction, the concept of 'relative poverty', which defines poverty within the limits of the views and expectations of the individual, gains validity. Relative poverty, which rises as a result of the comparison of an individual's life quality with a reference group having higher in- 
come (Șenses, 2001: 91), may be used to determine whether the individual is glad to live in the city or not.

It is possible to refer to relative poverty concerning the residents of prefabricated housing. A significant amount of these residents (40\%) regard themselves as poor compared to their surroundings (district). The majority classify themselves as the middle class; the number of residents who consider themselves to be richer than their surroundings is very small or none at all (Table 8).

Table 8 - Relative poverty, by district

\begin{tabular}{|l|c|c|c|c|c|}
\hline & $\begin{array}{c}\text { Poor as } \\
\text { regards } \\
\text { district }\end{array}$ & $\begin{array}{c}\text { Middle } \\
\text { class as } \\
\text { regards } \\
\text { district }\end{array}$ & $\begin{array}{c}\text { Rich as } \\
\text { regards } \\
\text { district }\end{array}$ & Other & Total \\
\hline Prefabricated housing & 85 & 195 & 9 & 8 & 297 \\
\hline Earthquake adapted settlements & 10 & 124 & 5 & 1 & 140 \\
\hline Total & 95 & 319 & 14 & 9 & 437 \\
\hline
\end{tabular}

A majority of the residents of prefabricated housing (60.9\%) regard themselves as poor when compared to residents of the city. Concerning earthquake adapted settlements, however, the percentage of residents who regard themselves as poor is relatively low $(17.1 \%)$. Among the residents of these settlements, there is an express tendency $(79.2 \%)$ to regard themselves as economically equal to residents of the city (Table 9).

Table 9 - Relative poverty as regards residents of the city

\begin{tabular}{|l|c|c|c|c|c|}
\hline & $\begin{array}{c}\text { Poor as } \\
\text { regards } \\
\text { district }\end{array}$ & $\begin{array}{c}\text { Middle } \\
\text { class as } \\
\text { regards } \\
\text { district }\end{array}$ & $\begin{array}{c}\text { Rich as } \\
\text { regards } \\
\text { district }\end{array}$ & Other & Total \\
\hline Prefabricated housing & 181 & 107 & 1 & 9 & 297 \\
\hline Earthquake adapted settlements & 24 & 111 & 4 & 1 & 140 \\
\hline Total & 204 & 218 & 5 & 10 & 437 \\
\hline
\end{tabular}

A majority of the residents of prefabricated housing in Bolu (55.6\%) regard themselves as economically equal to villagers. A similar tendency $(69.6 \%)$ was also noticed in earthquake adapted settlements (Table 10).

Table 10 - Relative poverty as regards village

\begin{tabular}{|l|c|c|c|c|c|}
\hline & $\begin{array}{c}\text { Poor as } \\
\text { regards } \\
\text { district }\end{array}$ & $\begin{array}{c}\text { Middle } \\
\text { class as } \\
\text { regards } \\
\text { district }\end{array}$ & $\begin{array}{c}\text { Rich as } \\
\text { regards } \\
\text { district }\end{array}$ & Other & Total \\
\hline Prefabricated housing & 80 & 119 & 19 & 214 & 80 \\
\hline Earthquake adapted settlements & 8 & 69 & 22 & 99 & 8 \\
\hline Total & 88 & 188 & 41 & 313 & 88 \\
\hline
\end{tabular}


In general, dissatisfaction with the current situation stands at the foreground in prefabricated housing, unlike in earthquake adapted settlements. The satisfaction of earthquake adapted settlement residents with their existing situation may be considered to facilitate their integration with the city while such an integration may be difficult to realise for residents of prefabricated housing who are dissatisfied with their situation.

\section{The way of life and survival strategies}

Inclusion in the city includes the adaptation strategies shaped by the urban eco-system. Such strategies aim at reducing instability and uncertainty as well as maximising the use of existing resources (Bartolomé, 1984: 180). It is not surprising that such an aim may affect the way of life. From the house and its surroundings to relations with neighbours and relatives, it is reflected in every part of the way of life, together with the struggle against poverty in order to survive in the city. In other words, factors concerning the way of life take a form in the manner of a survival strategy.

One of the factors concerning the way of life is housing. The house is among the most important variables which best reveal the way of life. For example, a squat is a symbol of a culture beyond just being a shelter. In such a case, it is possible to evaluate a squat from two perspectives: firstly, a squat 'as a house' which goes towards meeting a household's need for shelter, which is the basic necessity; and secondly the squat as a 'way of life', a squatting culture which is the extension of the village and which aims to integrate with the city (Onat, 1993: 15).

In this context, it must be clearly explained what is intended to be implied by 'way of life'. When a family's lifestyle is mentioned, what is understood is all the material and non-material factors; that is, the quantitative and qualitative factors extending from shelter to nutrition, from clothing to education and the way of life indicated by such factors (Dikeçligil, 1991: 524).

\section{Table 11 - Factors concerning the way of life}

\begin{tabular}{|l|l|}
\hline 1. Shelter & $\begin{array}{l}\text { Position and type of residence; number of rooms; selection of } \\
\text { furniture and goods for the house }\end{array}$ \\
\hline 2. Nutrition & Types, quantities and consumption of foods \\
\hline 3. Education & $\begin{array}{l}\text { Educational background and professions of family members; } \\
\text { educational institutions to which family members attend, if any, } \\
\text { and expectations of education }\end{array}$ \\
\hline 4. Clothing & Style, colour and quality of clothing \\
\hline 5. Health & Family's attitude towards health protection and in case of illness \\
\hline $\begin{array}{l}\text { 6. Entertainment } \\
\text { 7. Communication and } \\
\text { transportation }\end{array}$ & $\begin{array}{l}\text { Type of entertainment in which the family is interested; and the } \\
\text { means of entertainment }\end{array}$ \\
\hline & $\begin{array}{l}\text { The interests and habits in a selection of communications and trans- } \\
\text { portation means }\end{array}$ \\
\hline
\end{tabular}


8. Relationships
Relationship between family members; family's attitude towards incidents such as engagements, marriage, births and deaths; the language used; the level of abiding by good manners; respect for family members, relatives and neighbours

Source: Dikeçligil, 1991: 524.

These socio-economic variables, together with main variables such as educational background, profession, income and social roots, have a satisfactory potential to explain the major differences between various social strata without the need to reference other variables (Ayata and Ayata, 1996: 5).

Under these conditions, differences concerning the ways of life of various housing classes may be clarified by a sole consideration of basic variables such as kinship and neighbourhood and housing (shelter), without examining every factor listed above. In this way, survival strategies as regards ways of life may be comprehended.

\section{Kinship and neighbourhood}

Kinship and neighbourhood are types of social relations which are experienced more densely in community or, in other words, in life in the traditional/rural sector. Cities are settlements which put individual and secondary group relations forward; nevertheless, when we look at the situation from Wirth's point of view, then urbanisation is expected to impair primary group relations such as kinship and neighbourhood since the relationships of urban residents are impersonal, superficial, temporary and partial (Hassan, 1977: 35-36).

The level of kinship and neighbourhood could be evaluated on the basis of the frequency with which people visit each other and whether or not sources of material and moral assistance exist between them.

When the frequency of visiting one another was taken as a way of testing neighbourhood relations, it was noticed that most $(55.8 \%)$ of the residents of prefabricated housing meet their neighbours every day (Table 12). However, the frequency of visiting one another is rather low among the residents of earthquake adapted settlements $(38.5 \%)$. In this respect, it can be alleged that relations are weaker in earthquake adapted settlements when compared with prefabricated housing in terms of the frequency with which people visit one another.

Table 12 - Frequency of visiting neighbours

\begin{tabular}{|l|c|c|c|c|c|}
\hline & $\begin{array}{c}\text { Every } \\
\text { day }\end{array}$ & $\begin{array}{c}\text { Once a } \\
\text { week }\end{array}$ & $\begin{array}{c}\text { Once a } \\
\text { month }\end{array}$ & Other & Total \\
\hline Prefabricated housing & 166 & 22 & 8 & 101 & 297 \\
\hline Earthquake adapted settlements & 54 & 23 & 9 & 54 & 140 \\
\hline Total & 220 & 45 & 17 & 155 & 437 \\
\hline
\end{tabular}

In almost half of prefabricated housings in Bolu (49.8\%), relatives support each other in material respects (Table 13). However, material assistance between relatives is more explicit in earthquake adapted settlements $(66.4 \%)$. 
Table 13 - Material assistance between relatives

\begin{tabular}{|l|c|c|c|c|}
\hline & $\begin{array}{c}\text { We support } \\
\text { eachother }\end{array}$ & $\begin{array}{c}\text { We do not } \\
\text { support }\end{array}$ & Other & Total \\
\hline Prefabricated housing & 148 & 135 & 14 & 297 \\
\hline Earthquake adapted settlements & 93 & 43 & 4 & 140 \\
\hline Total & 241 & 178 & 18 & 437 \\
\hline
\end{tabular}

Moral support between relatives is available in most $(64.6 \%)$ of prefabricated housing (Table 14). As for earthquake adapted settlements, moral support between relatives is very high $(82.1 \%)$.

Table 13 - Moral support between relatives

\begin{tabular}{|l|c|c|c|c|}
\hline & We assist & $\begin{array}{c}\text { We do not } \\
\text { assist }\end{array}$ & Other & Total \\
\hline Prefabricated housing & 192 & 88 & 17 & 297 \\
\hline Earthquake adapted settlements & 115 & 18 & 7 & 140 \\
\hline Total & 307 & 106 & 24 & 437 \\
\hline
\end{tabular}

When co-operation between neighbours is considered, it is seen that material support is found mostly among residents of prefabricated housing (53.8\%) (Table 14). In contrast, in earthquake adapted settlements, the percentage of neighbours who help each other $(41.4 \%)$ is lower than the percentage of neighbours who do not help each other.

Table 14 - Material assistance between neighbours

\begin{tabular}{|l|l|l|l|l|}
\hline & $\begin{array}{c}\text { We support } \\
\text { eachother }\end{array}$ & $\begin{array}{c}\text { We do not } \\
\text { support }\end{array}$ & Other & Total \\
\hline Prefabricated housing & 147 & 137 & 13 & 297 \\
\hline Earthquake adapted settlements & 58 & 78 & 4 & 140 \\
\hline Total & 205 & 215 & 17 & 437 \\
\hline
\end{tabular}

When moral assistance between neighbours is in question, we can see that most (i.e. 69.6\%) of the residents of prefabricated housing assist each other (Table 15). It is interesting that a similar trend exists within earthquake adapted settlements. Furthermore, the percentage of moral support found in earthquake adapted settlements $(77.5 \%)$ is greater than the percentage found in prefabricated housing. When stepping from prefabricated housing to earthquake adapted settlements, the basis for neighbourhood relations slides from material assistance to moral support. In this context, if material assistance is regarded as a more powerful neighbourhood relationship, than it may be suggested that relations are weakened when passing from prefabricated housing to earthquake adapted settlements. 
Table 15 - Moral support for neighbours

\begin{tabular}{|l|c|c|c|c|}
\hline & We assist & $\begin{array}{c}\text { We do not } \\
\text { assist }\end{array}$ & Other & Total \\
\hline Prefabricated housing & 207 & 75 & 15 & 297 \\
\hline Earthquake adapted settlements & 106 & 31 & 3 & 140 \\
\hline Total & 313 & 106 & 18 & 437 \\
\hline
\end{tabular}

As is obvious, both material assistance and moral support are in question, particularly in prefabricated housing. In providing such assistance, poverty is shared in a way and also a kind of 'living together' is displayed. This action ensures continuous survival in a city by functioning as a survival strategy.

\section{Housing}

Housing is a significant indicator which should be considered in comprehending income and way of life. Housing standards accurately reflect income in so much that housing is the primary factor in indexes used in way of life and stratification research. Squats in modern cities reflect the income of low income groups with the same accuracy (Kiray, 2003: 22).

Differences between social strata may be apprehended by looking at housing characteristics since housing directly reflects way of life. Differences which occur during the processes of obtaining, using and changing houses basically originate from social strata characteristics. This appears foremost in the level of differentiation between squats and apartment buildings. A squat is smaller than an apartment and the functional separation of the place in such housing is not so developed (Ayata and Ayata, 2000: 153).

Under such conditions, differences between earthquake adapted settlements and prefabricated housing could be clarified by understanding such classes of housing.

The outside of housing, as well as the inside, gives significant clues pertaining to life in such housing. For instance, whether or not the gardens in front of apartment buildings are well-kept, or whether agricultural activities are carried out right in front of a squat, carry importance in this regard. Such agricultural activities are also notable in terms of being a survival strategy, ensuring inclusion in the city.

The manner of the preparation and handling of food, housing maintenance, the rearing of children and even small-scale agricultural activities in squatted gardens indicate the dimensions of production for survival. Middle-class families meet a significant part of household needs from the market while poor families provide reproduction for the family by making as much use as possible of domestic labour and raw materials and the handling of such materials. To a degree, they resist poverty by using the skills they have developed in order to handle domestic resources and raw materials. In particular for families who have just immigrated to cities, the transfer of rural survival production skills into the urban environment functions as a kind of 'survival strategy' following immigration to the city (Demir, 2002: 64).

Despite the lack of satisfactory areas in prefabricated housing in Bolu, ${ }^{2}$ it has been detected that a remarkable amount of small-scale agricultural activities is being carried out $(23 \%)$ (Table 16). Albeit that they are small-scale, but such agricultural activ- 
ities tend to allow residents to meet their main food needs, such as vegetables, on their own instead of buying from the market. Thus, it can be claimed that they are struggling to be included in the city by the 'survival strategy' they have developed.

Table 16 - Vegetable cultivation

\begin{tabular}{|l|c|c|c|}
\hline & Cultivates & Does not cultivate & Total \\
\hline Prefabricated housing & 56 & 144 & 200 \\
\hline Earthquake adapted settlements & 3 & 97 & 100 \\
\hline Total & 59 & 241 & 300 \\
\hline
\end{tabular}

On the other hand, the existence of outlying (additional) buildings also gives an idea regarding housing and the household. Squats in particular can be promptly distinguished from other housing types in this regard. Families in squats obtain their houses with difficulties, so they regard their house, together with its coop and vegetable garden, as a centre and, from such a position, the squat is much closer to a village house than to an urban building (Yasa, 1991: 133).

Bolu's prefabricated housing may be claimed to be similar to squats in terms of having outlying buildings. Most of these houses (74\%) have additional buildings, such as a store, closed balcony or other rooms (Table 17). Residents have various intentions for such outlying buildings, but especially in regard to storage for preserving vegetables that they have cultivated or brought from their villages to be used in winter.

Table 17 - Construction of outlying buildings

\begin{tabular}{|l|c|c|c|}
\hline & Constructed & Not constructed & Total \\
\hline Prefabricated housing & 147 & 53 & 200 \\
\hline Earthquake adapted settlements & 27 & 73 & 100 \\
\hline Total & 174 & 126 & 300 \\
\hline
\end{tabular}

\section{Conclusion}

Poverty directly affects the way of life and lays the groundwork for the occurrence of a 'poverty culture' by enabling the sustainability of rural characteristics. Prefabricated housing and earthquake adapted settlements are similar to each other in some way, but they do, in fact, have significant differences. In this regard, we see that the rural way of life exists in unity with poverty, yet such a way of life exhibits integral diversities. In other words, it does not seem possible to mention a uniform urbanisation process or a singular way of life.

On the other hand, a specific squatter-like way of life has arisen in prefabricated housing. Such a way of life shelters residents with a low educational background. Kinship and neighbourhood are strong where both material assistance and moral sup-

2 Only an area of $2-3 \mathrm{~m}^{2}$ between each prefabricated housing is used for this aim. 
port exist between relatives and neighbours. Relations between them are so intense that they meet every day. Poverty is shared by strong kinship and neighbourhood, cooperation and solidarity and, thus, a kind of 'living together' is displayed. This enables inclusion and survival in the city since it functions as a survival strategy.

Differences in ways of life between prefabricated housing and earthquake adapted settlements could also be mentioned in terms of housing styles. The variations between these two housing groups can be understood even from the outside of the housing. The cultivation of vegetables in the garden and the construction of outlying buildings attract attention in prefabricated housing although they are rarely encountered in earthquake adapted settlements. The cultivation of vegetables in prefabricated housing, like in squats, is another form of survival strategy, ensuring inclusion in the city. Vegetable cultivation contributes to the household budget and products are produced cheaper than can be obtained at the market. Another function of outlying buildings is that residents use these buildings to store their cultivated vegetables and provisions they have brought from the village for the winter. Thus, the house resided in functions in toto as survival strategy and enables the maintenance of life in the city.

\section{References}

Ayata, Sencer-Güneș and Ayșe Ayata (1996) Konut, Komșuluk ve Kent Kültürü (Housing, Neighbourhood and Urban Culture) Başbakanlk Toplu Konut ${ }^{\circ}$ daresi Bașkanığı Yay: Ankara.

Ayata, Sencer and Ayșe Ayata (2000) 'Toplumsal Tabakalașma, Mekansal Ayrıșma ve Kent Kültürü' Mübeccel Kray ${ }^{\circ}$ çin Yazılar ('Social Stratification, Locational Resolution and Urban Culture' Articles for Mübeccel Kıray) Bağlam Yay: İstanbul.

Bartolomé, Leopoldo J (1984) 'Forced Resettlement and the Survival Systems of the Urban Poor' Ethnology 23(3).

Demir, Erol (2002) 'Yeni Kentli Ailelerde Geçimlik Üretim ve Yoksulluk' ('Survival, Production and Poverty in Newly Urbanized Families') Planlama (Planning) Say:1, TMMOB Șehir Plancıları Odası.

Dikeçligil, Beylü (1991) 'Yașama Tarzı İle Gelir Seviyesi Arasındaki İlișki' ('Relationship Between Way of Living and Income Level') Aile Yazilar1 1 (Articles Regarding Family), Başbakanlık Aile Araștrma Kurumu Yay: Ankara.

Erder, Sema (1997) Kentsel Gerilim (Urban Tension) Uğur Mumcu Araștırmacı Gazetecilik Vakfı Yay: Ankara.

Erman, Tahire (1998) 'Farklılașan Kırsal Kökenli Cemaat, Değișen Gecekondu: Bir Etnografik Araștırmanın Gösterdikleri' ('Society with Rural Roots Which is Undergoing Change, Squatters' Camps: What Ethnographic Research Shows'), Sosyoloji Araștırmaları Dergisi (Sociological Research magazine): 1(1-2), Güz.

Gans, Herbert J (1962) 'Urbanism and Suburbanism as Ways of Life: A Re-evaluation of Definitions' Human Behavior and Social Process Houghton Mifflin Company, Boston.

Hart, Charles W. M (1969) Zeytinburnu Gecekondu Bölgesi (Zeytinburnu Squatter Region) İstanbul Ticaret Odası Yayını: İstanbul. 
Hassan, Riaz (1977) 'The Urban Environment and Mental Health' Questioning Development In Southeast Asia Select Books on Behalf of Southeast Asia Study Group, Singapore.

Karpat, Kemal (1976) The Squatter: Rural Migration and Urbanization Cambridge University Press: Cambridge.

Kıray, Mübeccel (2003) Kentleșme Yazıları (Articles on Urbanization) İkinci Basım, Bağlam Yay: İstanbul.

Lewis, Oscar (1959) Five Families: Mexican Case Studies in the Culture of Poverty Basic Books: New York.

Lewis, Oscar (2000) 'A Study of Slum Culture: Backgrounds for La Vida' From Modernization To Globalization, Blackwell Publishers: USA.

Onat, Ümit (1993) Gecekondu Kadınının Kente Özgü Düșünce ve Davranıșlar Geliștirme Süreci (Squatter Woman's Process of Developing Views and Behaviours Peculiar to Urban Life) Bașbakanlık Kadın ve Sosyal Hizmetler Müsteșarığlı Yay: Ankara.

Șenses, Fikret (2001) Küreselleșmenin Öteki Yüzü Yoksulluk (Poverty; Other Face of Globalisation) İletișim Yay: İstanbul.

Șenyapl, Tansı (1983) Ankara Kentinde Gecekondu Gelișimi (1923-1960) (Development of Squatters in Ankara City (1923-1960)), Kent-Koop Batıkent Konut Üretim Yapı Kooperatifleri Birliği Yayını: Ankara.

Randolf, David (1977) 'The Sociology of Poverty or The Poverty of Sociology?: A Brief Note on Urban Poverty Research' Questioning Development In Southeast Asia, Select Books on Behalf of Southeast Asia Study Group, Singapore.

Saunders, Peter (1984) 'Beyond Housing Classes: The Sociological Significance of Private Property Rights of Means of Consumption' International Journal of Urban and Regional Sciences 8.

Türkdoğan, Orhan (1974) Yoksulluk Kültürü, Gecekonduların Toplumsal Yapısı (Poverty Culture, Social Structure of Squatters) Atatürk Üniversitesi Yay: Erzurum.

Ulusoy, Mahir and Murat Kayıkçı (2006) Prefabrike Konutların Yoksulluk Adalarına Dönüșümü: Bolu Deprem Prefabrike Konutları Üzerine Bir Araștırma (Transfer of Prefabricated Housings into Slums; a Research on Bolu Earthquake Adapted Settlements) Abant İzzet Baysal Üniversitesi İdari ve Mali İşler Daire Bașkanlığ Bilimsel Araștırma Projeleri, Proje No: 2005.04.01.212, Bolu.

Wirth, Louis (1938) 'Urbanism as a Way of Life' American Journal of Sociology XLIV(1).

Yasa, İbrahim (1991) 'Gecekondu Ailesi' ('Squatter Family') Aile Yazılar1 1 (Articles Regarding Family 1), Bașbakanlık Aile Araștırma Kurumu Yay: Ankara. 